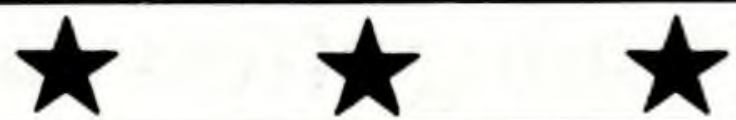

\section{Noutg fram the ffipld}

\section{Acquisitions}

- The Antique Automobile Club of America Library and Research Center, Hershey, Pennsylvania, has recently purchased the Russell E. Stadt Marmon literature collection. Compiled by hobbyist Russell E. Stadt, of Grand Rapids, this collection pertains solely to the revolutionary Marmon automobile invented by Howard Marmon in 1902. This was a technically advanced machine which incorporated automotive engineering devices not found in other makes of cars until 20 years later. The collection includes catalogs, photographs, owners manuals, parts books, factory service letters, blueprints, magazine articles, advertisements, and color chip samples.

- Arizona State University Libraries, Tempe, have acquired a substantial collection of materials on and by William Burroughs, the American experimental novelist of the 1950s and 1960s. These archives contain four feet of manuscripts dating from 1938, including source materials and several drafts of Burroughs's major works. Also included are two volumes of dream notes and three feet of clippings and other materials assembled by Burroughs, much of it during the Beat Hotel period with Byron Gysin in Paris.

- Cornell University Libraries, Ithaca, New York, have received a gift of materials produced by and about various groups and individuals that spearheaded student activism in the Ithaca area between 1966 and 1972. The donor is Lawrence E. Kramer, Cornell Class of 1970 and currently a freelance writer in New York City. The collection contains 200 pages of information that the FBI and other Federal agencies collected about the donor as part of their surveillance of campus dissidents, as well as many leaflets, newsletters, and discussion papers distributed by Cornell-based antiwar and New Left organizations.

- Eastern Michigan University Library, Ypsilanti, has been given a collection of books and other materials by and about Aldous Huxley (1894-1963). The donor is David K. Maxfield, a retired university librarian living in Ann Arbor. Several items are autographed by Huxley, including a letter to Maxfield concerning the novel, Time Must Have a Stop. In addition to over 100 books, there is a complete file of Huxley's syndicated contributions to the Hearst newspapers clipped from the Chicago Herald and Examiner, and tear sheets of articles by and about Huxley.
- Kansas State University Libraries, Manhat$\tan$, have acquired the Fred and Jeannette Higginson Collection of Robert Graves books. Higginson, the bibliographer of Graves, has assembled nearly 600 works by and about the English poet and author of $I$, Claudius that add to the nearly 300 books already acquired by the Libraries.

Other KSU acquisitions include: an extensive collection of Lincolniana from the private library of Rex Anderson; nearly 900 books on poultry, ranging from scientific publications to children's stories; over 200 books, several "little magazines," and correspondence of Donald von Ruysdael Drenner, who operated the private Zauberberg Press from 1946 to 1966 in Coffeyville, Kansas; and several hundred private press printings of poetry, calendars, avant garde publications, catalogs, and books about private presses.

- North Park College and Theological Seminary, Chicago, has received a major portion of the library of the late Walter Johnson, noted scholar and teacher of Scandinavian literature, who died in February 1983. The collection is rich in materials on Strindberg and other Swedish writers, as well as Norwegian, Icelandic, Danish and Finnish poetry, literature and history. The collection exceeds 1,000 volumes.

-The Ohio State University Libraries, Columbus, have acquired a collection of the papers of Bernard A. Bergman (1894-1980), managing editor of the New Yorker in 1931-19.33 who later was associated with a number of Philadelphia newspapers, including the Philadelphia Bulletin in 1961-1980. The papers, primarily gathered for an autobiography that was never completed, include unpublished accounts of his experiences with his feature column for the Hearst newspapers in 1933-1935 and with the New Yorker, the text of several addresses, and briefer sketches of many writers and journalists with whom he had been associated.

- The San Jacinto Museum of History, La Porte, Texas, has received a gift of 46 historical manuscripts and documents from Mr. and Mrs. James L. Britton, of Houston, covering important events in the struggle for possession of Texas in the early 19th century. Among the high points in the collection are several items concerning the Texas Revolution, including an 1836 letter from Secretary of War Thomas Rusk ordering Colonel James Morgan to arrest four Anglo-Texans felt to be spies, and the printed broadside of William Travis's last letter 


\section{Only Meckler Publishing offers complete coverage of}

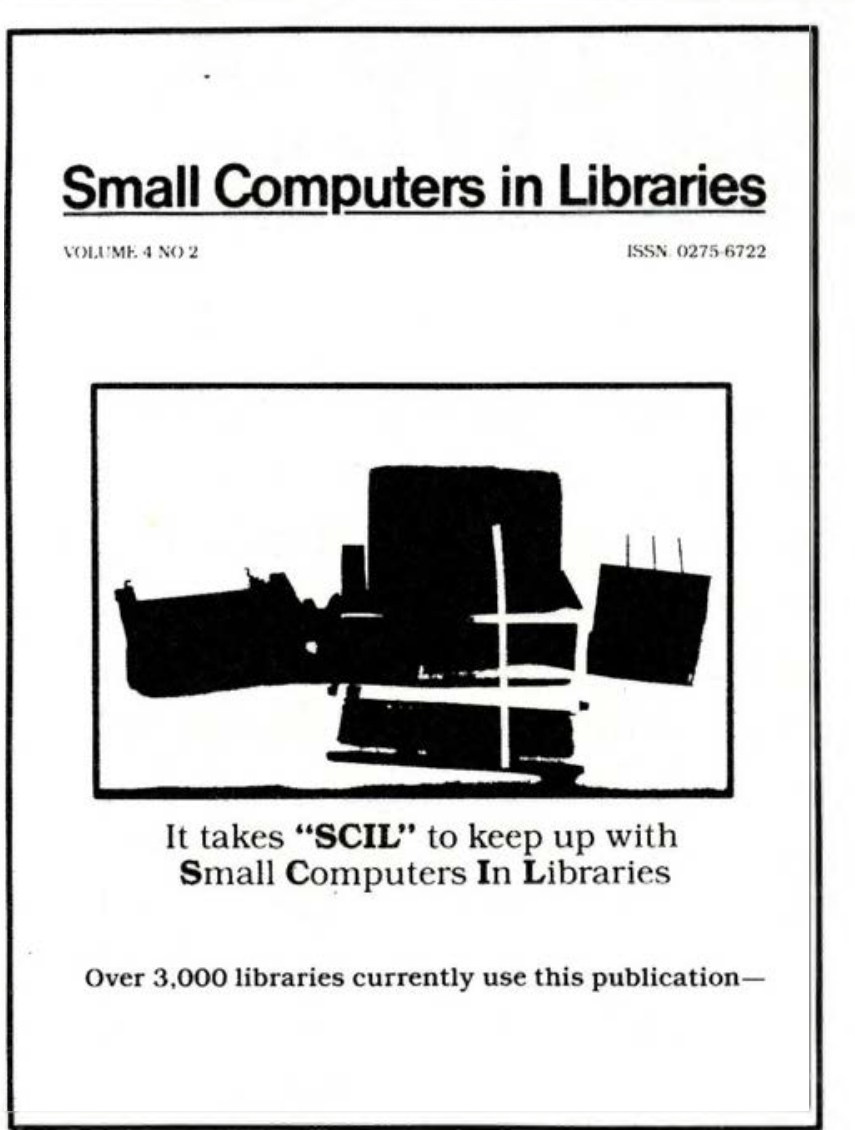

SMALL COMPUTERS IN LIBRARIES (SCIL) is a monthly newsletter that offers every librarian the guidance for evaluating microcomputers and associated peripherals. SCIL also keeps librarians informed about reference services for computers, user groups, and materials for more effective microcomputer operations.

Pricing: Available monthly @ $\$ 24.00$

Editor: Allan Pratt

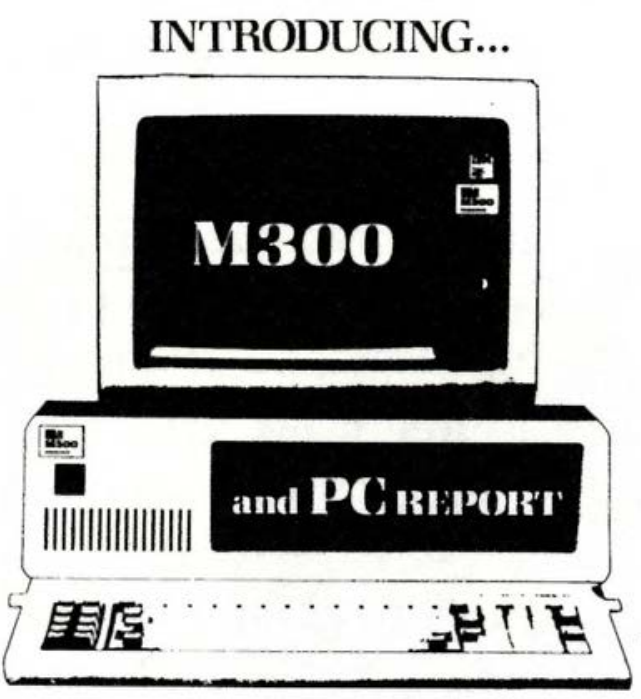

A monthly publication to keep your library abreast of $M 300$ and IBM PC developments
The M300 and PC REPORT is a monthly newsletter providing information on developments, trends, forecasting, and use of the M300 and IBM PC as a technical processing, library management, and collection access tool. Also, every issue contains practical reports on installations, integration, and effective use. Finally, reports are provided on new programs from library supply agencies written for use on the IBM PC as well as pre-written software available for library applications.

Pricing: Available monthly @ \$29.00

Editor: Nancy J. Melin

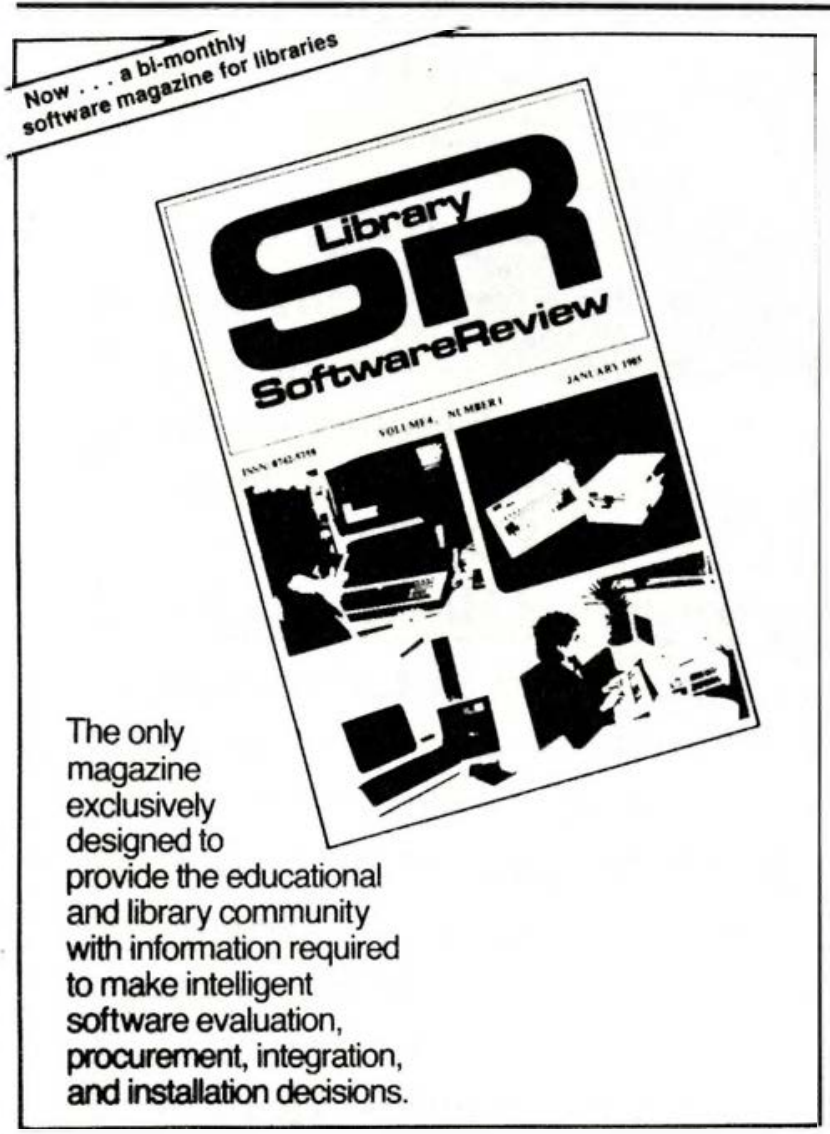

LIBRARY SOFTWARE REVIEW is the only magazine exclusively designed to provide the library user with information required to. make intelligent software evaluation, procurement, integration, and installation decisions. Its coverage is inclusive of both prewritten software as well as software in development for micros, minis, and library oriented mainframe computers. In addition to articles and reviews of software, each issue offers reviews on software books, periodicals, and other materials pertaining to computer software with relevance to libraries.

Pricing: Available bi-monthly @ \$69.50

Editor: Nancy J. Melin 


\section{microcomputers and software for you and your library.}

\section{Library Software Conference \& Exposition}

\section{The Hyatt Regency, Columbus, Ohio, October 2-4, 1984}

\section{Why You Should Attend}

Here is an opportunity to participate in a unique national gathering designed solely to identify, describe, and present software applications for library and educational communities.

Now, Meckler Publishing, in conjunction with its magazine LIBRARY SOFTWARE REVIEW, provides this distinguished forum for library software managers, media department directors, computer department representatives, technical service officials, and other individuals whose responsibilities require knowledge of available software and associated products.

\section{Conference Agenda (Panel Presentations)}

- Local Area Networks

- Software Copyright Issues

- Public Access Bulletin Boards

- Computer Literacy

- Gateway Software

- Tools and procedures for selecting and purchasing software
- Sources for information about software

- Public Domain Software

- Product Reviews

- Telecommunications

- Field trip to OCLC

- Online: Mainframe vs. micro

\section{Featured Speakers (Partial listing)}

Patrick Dewey

Administrative Librarian,

Mayuood Public Library (II.)

and autbor. PUBLIC ACCESS

MICROCOMPUTERS IN LIBRARIES:

A HANDBOOK FOR LIBRARIANS

Hal W. Hall

Special Formats Librarian, Texas $A$ \& $M$ University

Martin Kesselman

Editor, "Online Update," WILSON

LIBRARY BULLETTN and Reference

Librarian, New York University

Chuck Lynd

Information Specialist, LINC Resources (Columbus, OH)
David MacDonald

Head, Systems Office: University of Michigan Libraries

Nancy Jean Melin

Conference Coordinator and Editor, LIBRARY SOFTWARE REVIEW and $M 3 O O$ and PC REPORT

Gail Persky

New' York University Libraries

Paul Peters

Assistant University Librarian for Systems, Columbia University

Allan Pratt

Editor, SMALL COMPUTERS IN LIBRARIES: Professor, Graduate Scbool in Librarianship, University of Arizona
James E. Rush

President, James E. Rusb Associates

Michele Sinesky Computerized Education, (Trenton, NJ)

Tom Surprenant Associate Editor, LIBRARY HI TECH: Associate Professor, Graduate School of Library and Information Science, University of Rhode Island

Ken Thomas M300 Project Manager, OCLC, InC.

Daniel Toohey Attorney; Dow, Lobnes \& Albertson (DC)

Registration Information: $\$ 175.00$ or $\$ 95.00$ per day. Room rates: single, $\$ 68.00$; double, $\$ 75.00$

\section{Order Form}

\section{Enter an order for the following:}

$\square$ Small Computers in Libraries at $\$ 24$

$\square$ M300 and PC Report \$29

$\square$ Library Software Review Volume 4, 1985 (Bi-monthly) at $\$ 69.50$

$\square$ Also, send registration information for the Library Software Conference

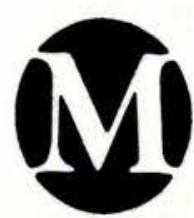

Meckler Publishing

520 Riverside Ave.

Westport, CT 06880 203-226-6967

Name

Organization

Address 
from the Alamo.

- The University of Illinois, Urbana, has recieved a gift of 200 hardcover science fiction, fantasy, and mystery titles from Steven Jaffe, of Skokie, Illinois. The books are all first editions in excellent condition and will be housed as a special collection in the Rare Book Room. Among the authors represented are Isaac Asimov, Robert Silverberg, Clifford Simak, and Edgar Rice Burroughs.

Illinois's Asian Departmental Library has been given a large collection of current Korean language publications by the Korean Research Foundation in Seoul. Through a matching fund agreement, the Foundation's gift is valued at $\$ 15,000$.

- The University of Southern California, Los

Angeles, has been given the papers and memorabilia of the late Ernst Matray, a leading figure of the Austrian and German theater from 1910 to 1936 , when he moved to California to work in Hollywood as a choreographer. The gift includes many of Matray's original drawings and theatrical sketches, as well as playbills and correspondence.

- The University of Waterloo, Ontario, Library has acquired a collection of 35,000 issues of women's periodicals published in England from 1893 to 1977. The collection is made up of the publisher's archive or file copies of various titles which were produced primarily by Amalgamated Press and its parent company, the Periodical Publishing Company. The Press was established in 1891 by Alfred Harmsworth for the sole purpose of publishing women's magazines directed at the expanding middle class market of women wanting guidance in home management and enjoyable reading. One of the longest runs is Woman's World: A Home Journal for the Everyday Lady, which appeared regularly from 1903 to 1958.

- The University of Wyoming Libraries, Laramie, acquired their 100,000th map last April. Titled Territory of Wyoming, the map depicts the Territory as it existed in 1876. The map was engraved and printed by Julius Bien for the General Land Office of the U.S. Department of the Interior. A public ceremony dedicating the acquisition was held on June 13 in the Documents and Maps Department of Coe Library.

- Wheaton College's Billy Graham Center Archives, Wheaton, Illinois, have received the personal papers of Charles W. Colson, former special counsel to President Nixon. The collection includes Colson's files relating to his trial, manuscripts of his books Born Again and Life Sentence, administrative memos of the Prison Fellowship staff, and materials from the promotion of the film, Born Again. Of special interest are White House files that Colson took with him when he left the White House staff; the same restrictions apply to these papers as those on the Nixon administration files in the National Archives. Restrictions on the Colson collection will be lifted as restrictions on the National Archives materials are lifted.

\section{Grants}

- The Academy of Natural Sciences of Philadelphia Library has received a grant of more than $\$ 130,000$ from the U.S. Department of Education for the cataloging and conservation of its photographic collection. The goal of the project is to catalog 20,000 images at the item level in a database management microcomputer program. The collection includes motion pictures, lantern slides, stereographs, albums, and portraits of 19th and 20thcentury figures in natural history.

- Brown University Library, Providence, has been awarded a $\$ 114,339$ grant by the National Endowment for the Humanities in support of its bibliography of European books about America printed between 1493 and 1776. The first two volumes of the six-volume series, entitled European Americana: A Chronological Guide to Works Printed in Europe Relating to the Americas, were published in 1980 and 1982 and two more volumes are currently in press. When completed, the series will include some 33,000 separate entries, more than three times the listings for the same period in the preceding series edited by Joseph Sabin.

- Cornell University Libraries, Ithaca, New York, have received an HEA Title II-C grant in the amount of $\$ 99,734$ to begin preparation of an ornithology online catalog. The project will add all manual catalog records of ornithology materials at Cornell to the RLIN database, including materials in sets, in reports of scientific expeditions, and in related zoological fields.

- The Fenway Library Consortium has been

\section{Statistics will be compiled for 1983-84}

The ACRL Board of Directors has approved funding for the compilation of statistical data for the approximately 100 university libraries in the U.S. and Canada which do not belong to the Association of Research Libraries. This study will update ACRL University Library Statistics 1981-82 and ACRL University Library Statistics 1978-79.

The questionnaire, modeled on the form used by ARL for its ARL Statistics, will be sent to library directors in late September. The institutions participating in the survey will be those in the Carnegie Classifications of DoctorateGranting Universities I and II. Questions about the project should be directed to Sandy Whiteley, ACRL/ALA, 50 E. Huron St., Chicago, IL 60611-2795.

Copies of the earlier titles in the series are still available from ACRL (prepaid only) as follows: 1978-79 volume, $\$ 5$ for members, $\$ 7.50$ for non-members; 1981-82 volume, $\$ 12$ for members, $\$ 15$ for non-members. 
awarded a grant of $\$ 15,050$ for an automation feasibility study. The project is funded through the Massachusetts Board of Library Commissioners with LSCA Title III funds. The grant will support a self-study to analyze and evaluate the Consortium's automation needs, establish long-range goals, and develop a strategy for implementation. The Consortium is composed of 12 academic and research libraries in Massachusetts.

-The Harwood Foundation Library, Taos, and New Mexico Highlands University Library, Las Vegas, have received a $\$ 10,000$ Interlibrary Cooperative Grant from the New Mexico State Library to develop at Harwood the capability of providing academic support to higher education in Taos. The funds will be used to develop orientation materials for students and to work with Highlands University staff to coordinate the acquisition and loan of materials. A user's guide will also be developed to describe the Harwood policies, collections, and services, and an instructor's guide describing these services will be distributed to the faculty of Highlands and Northern New Mexico Community College.

- The Indiana Newspaper Project, a cooperative effort of the Indiana State Library, the Indiana Historical Society, the Indiana Cooperative Library Services Authority, and the Indiana University Libraries, has been funded by a grant by the National Endowment for the Humanities. The Project received $\$ 175,000$ to create an online union list of newspaper holdings within the state, with an additional $\$ 54,000$ available for the project on a matching basis.

- Oglala Lakota College, Kyle, South Dakota,

\section{Overseas library exchanges}

During the 1984-85 academic year the General Directorate of Libraries of the French Ministry of Education will send a professional librarian to work in the Ohio University Libraries, Athens, as part of an exchange program under the sponsorship of the FrancoAmerican Commission under the Fulbright Accords. The American exchange librarian, Michel S. Perdreau, archives librarian at Ohio University, returned recently from his sevenmonth assignment at the Bibliotheque de Documentation Internationale Contemporaine at Nanterre, on the campus of Université Paris X.

The United States-United Kingdom Educational Commission has arranged for two Fulbright Fellowship exchanges in 1985. Andrea Singer, Indiana University, will switch jobs with Susan Telfer from the University of Surrey; and Dale Reed from Stanford University's Hoover Institution will trade places with Alistair Tough, University of Warwick. has received a $\$ 46,835$ grant from the National Historical Publications and Records Commission to establish and administer an archives and records management program for the Oglala Sioux tribe.

- Rutgers University's Institute of Jazz Studies,

New Brunswick, New Jersey, has been awarded a grant of $\$ 133,807$ by the National Endowment of the Humanities for a two-year project that will include the preservation, cataloging and indexing of the Institute's rare and unique sound recordings and the physical protection of their extensive clipping files. The grant will fund the transfer of approximately 800 sound recordings to archival quality audio tape using state-of-the-art sound restoration equipment. The 4,000 jazz performances will then be cataloged online and distributed through the IJS Jazz Register and Indexes.

-The University of Alberta, Edmonton, has received a $\$ 25,000$ grant from Canada's Social Sciences and Humanities Research Council and $\$ 5,000$ from the Clifford E. Lee Foundation to help fund the acquisition of the Curwen Press's own in-house collection of all the books, posters, and ephemera printed by the British firm in 1919-1956. The collection will strengthen the library's 20th-century fine printing collection, which is highlighted by major holdings of the Grabhorn Press and Canadian private presses.

- The University of Arizona's Center for Crea-

tive Photography, Tucson, has been awarded a $\$ 10,000$ community support grant by the Tucson Community Cable Corporation for the purchase of video equipment allowing the Center to make public access programs on photographers and photography. The programs will include interviews with visiting and local photographers.

- The University of California, Riverside, Library has been awarded $\$ 103,357$ to participate with four other research libraries in a joint cataloging project. This award is part of a joint $\$ 608,522$ HEA Title II-C grant. The project is being coordinated by the Indiana University Libraries in cooperation with Riverside, the University of Arizona, the University of Delaware, and the University of Utah. The purpose of the project is to create full cataloging records in machine-readable form for 25,200 books selected from the Wing Short-Title Catalog of English-language books printed between 1641 and 1700. The records will be created through OCLC.

- The University of Oregon, Eugene, has received a $\$ 56,000$ grant from the National Endowment for the Humanities to improve its Research Collection for Conservative and Libertarian Studies. The grant will be used to arrange the collections and upgrade the inventories of the alreadyprocessed materials, which include more than 50 groups of papers and files from the conservative and libertarian thinkers of the 1940s through the 1960s. 
-The University of Pittsburgh Library has received a \$36,268 grant from the National Historical Publications and Records Commission to make preservation copies of cellulose nitrate negatives in the Archives of Industrial Society. The negatives document the urban and industrial history of Pittsburgh in the 1920s and 1930s.

- The University of Texas at Austin's Benson Latin American Collection has been awarded a $\$ 184,944$ HEA Title II-C grant to underwrite a project to catalog 10,000 monographs on Latin America and add the entries to the OCLC database.

- The University of Wisconsin GeologyGeophysics Library, Madison, has received a $\$ 10,000$ grant from the Lewis G. Weeks Bequest Fund, administered by the Department of Geology and Geophysics, for the purchase of African geological survey publications and other titles on the geology of Africa.

- The West Texas Union List Project has been awarded a grant of $\$ 34,366$ by the Texas State Library and Archives Commission. The project will be a cooperative effort of Texas Tech University Library, the Lubbock City-County Library, the Texas Tech University Law Library, and the University of Texas of the Permian Basin. The Union List will facilitate increased sharing of serials resources and cooperative development of serials col- lections in West Texas. Carol M. Kelley, Texas Tech University Library, will serve as project director for the grant.

- Williams College Library, Williamstown, Massachusetts, has received a grant of $\$ 25,000$ from the Morgan Guaranty Trust Company of New York to purchase 1,500 music recordings and 300 scores and to recatalog the music collection on OCLC.

\section{News notes}

- The Columbia University Teachers College Library, New York, was able to supply the International Rescue Committee with the only known copies of 16 Dari-language textbooks, urgently needed for the schooling of Afghan refugees in Pakistan. Photocopies of the books were rushed to the Committee, whose headquarters are in Peshawar, Pakistan, where they will be reproduced for use in camps housing about 3 million refugees, half of whom are children under 14 . The texts, which are suitable for grades one through six, were written by Afghan educators who received technical assistance from Teachers College in a Curriculum and Textbook Project sponsored from 1966 to 1977 by the Agency for International Development.

-The State University of New York at Albany Friends of the Libraries won a Friends of Libraries

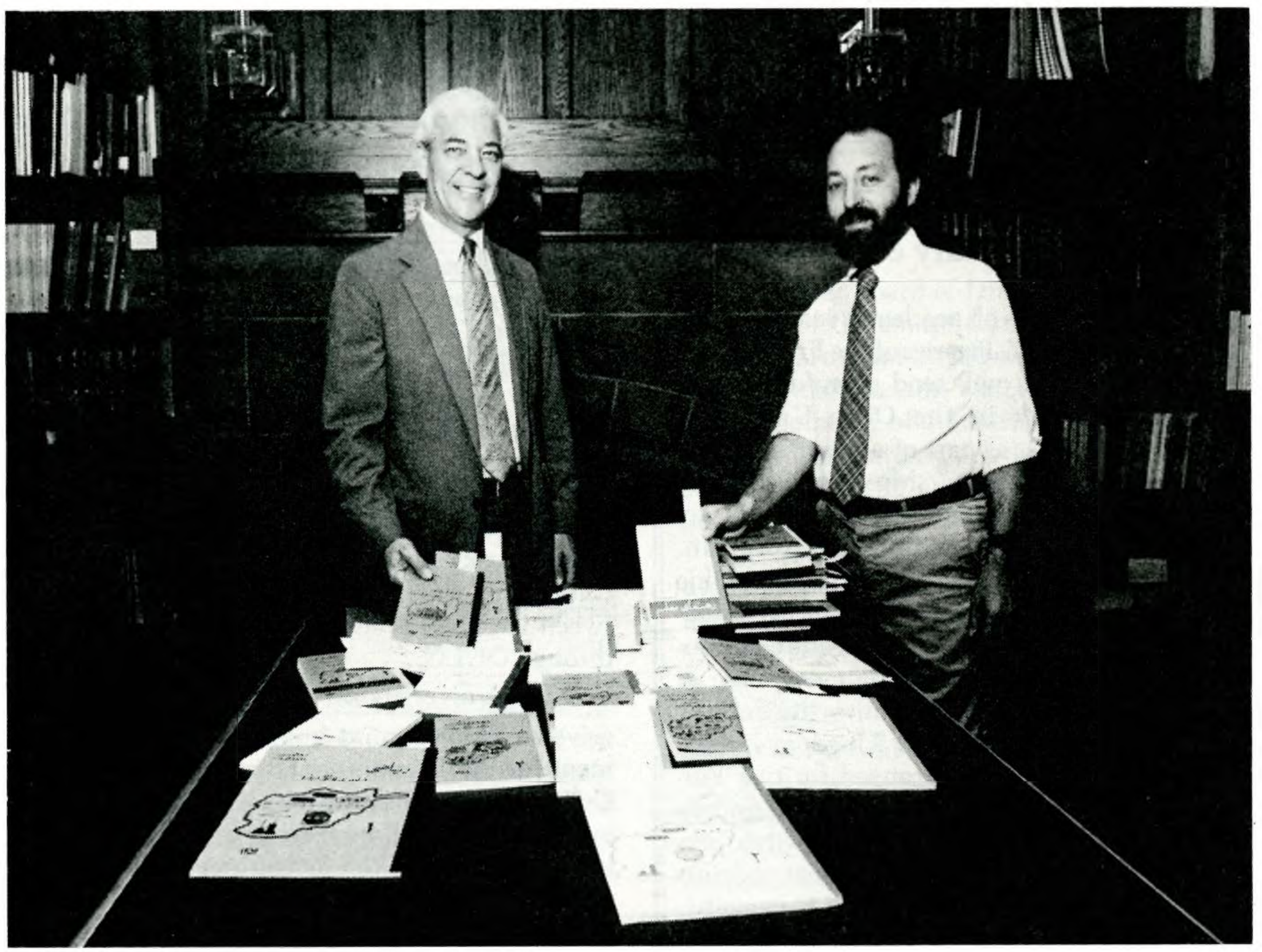

Thurston A. Atkins (left), professor, and David Ment (right), head of Special Collections at Teachers College/Columbia University, exhibit the library's collection of Dari-language textbooks. 
U.S.A. award for creative programming and membership development. Anne Roberts, associate librarian and liaison to the SUNY Friends, accepted the award during a ceremony at the ALA Conference in Dallas. In the past year the Friends group has held a series of noontime talks highlighting faculty explorations in their research, author receptions, and overnight outings and bus trips. The group has been cited as a model for academic Friends organizations.

\section{- PEOPLE・}

\section{Profiles}

LINDA BEAUPRÉ has been named associate director of General Libraries at the University of Texas at Austin. Her appointment is a promotion from associate director of public services, a position she has held since 1980.

Beaupré joined the UT Austin staff as head librarian of the Reference Services Department in 1978 and served as acting assistant director for public services from 1979 to 1980 . Previously she held the positions of associate university librarian for public services at the Moffitt Undergraduate Library, University of California, Berkeley, in 1977-1978, where she had started as a reference librarian in 1972; and supervisor of Microform Collections at the University of Michigan Graduate Library in 1967-1969.

Beaupré served on the College \& Research Libraries News Editorial Board from 1980-1984 and as chair of the RASD Nominating Committee. She has also worked on the ALA Instruction in the Use of Libraries Committee, the RASD Publications Committee, and on what is now the LAMA Library Organization and Management Section's Comparative Library Organization Committee. Currently a member of the Editorial Board for the Journal of Academic Librarianship, she holds an MLS from the University of Michigan.

Alan Benenfeld, coordinator of physical sciences and technology libraries at UCLA since 1976, has been named dean and director of libraries at Northeastern University, Boston, effective November 15 .

Benenfeld received his master's degree in management from Northeastern in 1975. Prior to his graduation there he received an engineering degree from NYU in 1961 and an MLS from Rutgers in 1965. He was a research assistant in metallurgy at
Cornell University from 1962 to 1964 . In 1965 he moved to MIT where he was first assistant engineering librarian, then a research staff member in the Electronic Systems Laboratory, and finally as a systems analyst and senior information scientist.

Benenfeld was technical program chairman for the ASIS Anaheim conference in 1980 and cochairman of the ASIS conference technical program in 1975. He was president of the Rutgers Student Chapter of ASIS and of the New England Chapter in 1969.

He has served on numerous ALA committees, including the ACRL Science and Technology Section's Conference Program Planning Committee for Dallas, the RASD Standards and Guidelines Committee and Publications Committee, and the LITA Editorial Board.

MiCHAEL K. BUCKLAND has been appointed assistant vice-president for library plans and policies for the University of California, effective July $1 . \mathrm{He}$ has been acting assistant vice-president since $\mathrm{Au}$ gust 1983, while concurrently serving as dean of the School of Library and Information Studies at UC-Berkeley. He resigned as dean in August.

Buckland was head of the Library Research Unit of the University of Lancaster, England, before moving to the U.S. in 1972 to become assistant director of libraries for technical services at Purdue University, Indiana. He joined UC as dean in 1976.

Buckland holds degrees from Oxford University and Sheffield University. His publications include two books and several reports and articles on library problems, management, and education.

David H. Eyman has been named head librarian of Skidmore College, Saratoga Springs, New York, effective July 2. Eyman has been director of libraries at Juniata College, Huntingdon, since 1978.

Eyman has earned a master's degree in history 